\title{
ADAPTATION OF PLASTIC WASTE TO ENERGY DEVELOPMENT IN LAGOS: AN OVERVIEW ASSESSMENT
}

\author{
O. Adekomaya ${ }^{1, *}$ and K. $0 \mathrm{jo}^{2}$ \\ 1, 2 Department of Mechanical Engineering, Olabisi Onabanjo University, ago Iwoye, OGUn State. NiGERIA \\ E-mail addresses: ${ }^{1}$ oludaisiyetunde@gmail.com, ${ }^{2}$ ojooos@tut.ac.za
}

\begin{abstract}
In view of the financial challenges experienced currently by government at all level in Nigeria occasioned by dwindling oil and gas revenue, this paper evaluates the possibility of adapting plastic waste to energy development for sustainable growth. Volume of wastes for the month of January, July and September, 2014 were reported to be $340,016.62 \mathrm{~m}^{3}, 302699.59 \mathrm{~m}^{3}$ and $298791.81 \mathrm{~m}^{3}$ respectively as contained in a report released by LAWMA. These specific months were primarily used as a case study to portray the fact that all measures put in place by government may not after all give required results. Although governments is making spirited efforts to reduce waste volume to considerable size, there appear to be unsurmountable obstacles ahead. These published waste volume results show clearly that wastes generated in Lagos is on the high side and concerted efforts need to be sustained in other to effectively contain these wastes. At a time, government is finding it difficult to generate adequate power supply to residence, the authors therefore recommend that alternative source of energy could be explored from these wastes which invariable may boost the economic fortunes of the people. The authors equally discussed some of the energy recovery process that may aid the reduction of waste volume in Lagos state.
\end{abstract}

Keywords: Plastic wastes, Energy, Sustainable development, Environment, Government.

\section{BACKGROUND STUDY}

Nigeria is currently faced with the challenge of waste management couple with the dwindling oil revenue due to its overdependence on conventional energy. Energy generation is reported to be a global need and countries that have recorded improved power generation and distribution is now battling with increased energy demand which has made some countries to be rationalising energy supply to their people. Nigeria seems to have been in energy deficit for a long time and successive governments have not been able to tackle this crisis head-on. Sourcing for revenue to tackle this need may be a mirage in view of global energy market which has further worsen in recent times as evidenced in the price of crude oil. Nigeria solely depend on petroleum resources to source for income to tackle infrastructural gap and also natural gas has always remains most viable option of energy generation in the countries. Analysts $[1,15]$ have even predicted that fossil fuel may no longer be a reliable source of energy generation in some years to come in view of its volatility and most importantly, it is not sustainable. It is therefore imperative for government to expedite action on how to develop a more sustainable blueprint on energy growth and expanding the existing source of energy in other to broaden power base of the country. Various researchers $[8,11]$ have exploited plastic wastes for potentials energy generation as seen in many publications, plastics wastes are now receiving attention for possibly full scale economic activity as various environmentalists[13, 14] have emphasized plastic waste as a source of energy considering its recyclability and affordability. According to OyakeOmbiset al [23], Lagos is believed to be generating highest volume of plastic wastes in Nigeria and this volume may triple in the couple of year if efforts are not geared toward redirecting the waste to economic fortunes of the country. This literature review is aimed at adapting this estimated volume of wastes in Lagos with a view to recommend the most approximate method of converting the wastes for energy development. 
It has been reported by many authors $[24,30]$ that the economic and environmental advantages of plastic wastes may far exceed metallic wastes if it is properly integrated for human need. Plastic waste is recyclable and therefore could be used for agricultural manure as reported in some literatures $[17,20]$.The invention of plastics has revolutionised the world as these plastic materials are evidently seen in homes in different forms due to its peculiarities. To properly situate the proportion of plastic in homes, a preliminary assessment of wastes volume was undertaken by [29, 31] to estimate percent content of plastic wastes in commonly used appliances. According to the authors, it was confirmed that plastic wastes account for larger wastes volume globally in homes due to its friendly nature (see Table 1 and 2). Table 1 depicts the percent of plastic in every volume of waste estimated and it is crystal clear that weight fraction of plastic appears high among all other wastes which is a clear signal that once plastic waste is contained, insignificant volume may henceforth be left as waste. In table 2, further analysis was done to estimate the proportion of plastic waste in home appliances and the report was presented in the table under study. This analysis further validated our earlier position that plastic waste constitute larger portion of waste in Nigeria.

Table 1: Percent content of plastic wastes[32]

\begin{tabular}{lc}
\hline Waste types & \% weight \\
\hline Plastic & 57 \\
Paper and cardboard & 10 \\
Wood & 3 \\
Textiles & 3 \\
Inerts and others(including & 27 \\
metals) & \\
Total & 100 \\
\hline
\end{tabular}

The concept of plastic engineering was first studied in early 1900s, and the world has never remain the same since then. Plastics has continuously replaced many types of materials such as wood, metals and ceramics due to its inherent properties and the fact that it is a poor conductor of heat further enhances its usefulness. Its relative weight advantages have continued to draw market to plastic as they are light, durable, and resistant to corrosion [4]. Diverse literatures $[11,19]$ have reported that light weight material are currently being used in automobile to reduce payload which ultimately reduces fuel consumption. Higher payload mean higher fuel consumption. Plastic materials are generally lighter and always have lower thermal conductivity. These two advantages makes plastic find market in homes and automobile industries[8].

Nigeria solely depend on fossil fuel to boost its energy supply as seen in government policy to increase the supply of LNG to most of the power plants. This attempt has always been a short time measure since the menace of fossil fuel outweigh its immediate gains. In view of the prevailing threat to the ecosystem and the need to preserve the nature for the unborn generation, the world is faced with emerging and undaunted challenges to combat climate change headon or face the looming and imminent disaster. Fossil fuel has been the major contribution to climate change and global warming. Depletion of ozone layer is worst affected by emission of carbon-monoxide which fossil fuel breed. It is therefore necessary to take proactive measure to develop a more pragmatic approach to covert this waste for sustainable development. Biron [12] had reported the need to diversity material usage which has both technical and economic consequences in view of the cost involved in waste management. Material wastes generated in Lagos continue to pose a challenge to and some of the wastes have defiled existing measures. Lagos being the economic hub of the nation needs special pilot strategy to reduce waste volume. Kofoworola [21] had reported some of the findings on Lagos wastes to be 4 million tonnes of municipal solid waste (MSW) as at 1995(see Table 3) and this is a far cry to what is presently generated in the year 2015[4].

Table 2: Contents of plastic proportion in home appliances in percentage[29].

\begin{tabular}{lcccccc}
\hline Appliances & Plastic (\%) & Aluminium (\%) & Copper (\%) & Steel (\%) & Glass (\%) & Others (\%) \\
\hline PC(CRT monitor) & 23 & 14 & 7 & 21 & 30 & 5 \\
Air conditioner & 11 & 7 & 17 & 55 & 0 & 10 \\
TV set & 23 & 2 & 3 & 10 & 57 & 5 \\
Refrigerator & 40 & 40 & 3 & 4 & 50 & $<1$ \\
Washing machine & 36 & 3 & 4 & 53 & $<1$ & 4 \\
\hline
\end{tabular}


Table 3: Waste generated in Lagos as at 1995[21].

\begin{tabular}{lllll}
\hline Reference point & $\begin{array}{l}\text { Estimated } \\
\text { Population(millions) }\end{array}$ & Year & $\begin{array}{l}\text { Municipal waste } \\
\text { generated(tonnes) }\end{array}$ & $\begin{array}{l}\text { Annual statistics } \\
\text { (tonnes/cap/year) }\end{array}$ \\
\hline Lagos & 10 & 1995 & 4 million & 0.40 \\
\hline
\end{tabular}

Table 4:Waste volume for the month of January, 2014(Cubic meter)

\begin{tabular}{lllll}
\hline $\mathrm{S} / \mathrm{n}$ & $\begin{array}{l}\text { Landfill } \\
\text { sites }\end{array}$ & $\begin{array}{l}\text { Truck } \\
\text { trips }\end{array}$ & $\begin{array}{l}\text { Total } \\
\text { (cubic meters } \\
\text { of refuse) }\end{array}$ & Remarks \\
\hline 1 & Olusosun & 10206 & 185529.10 & 55 \\
2 & Solous ii & 2024 & 38020.79 & 11 \\
3 & Solous iii & 3000 & 54966.74 & 16 \\
4 & Ewuelepe & 1522 & 36704.78 & 11 \\
5 & Epe & 1062 & 24795.21 & 7 \\
& Total & 17814 & $340,016.62$ & \\
\hline
\end{tabular}

Source: LAWMA

Table 5: Waste volume for the month of July, 2014(Cubic meter)

\begin{tabular}{lllll}
\hline S/n & $\begin{array}{l}\text { Landfill } \\
\text { sites }\end{array}$ & $\begin{array}{l}\text { Truck } \\
\text { trips }\end{array}$ & $\begin{array}{l}\text { Total } \\
\text { (cubic meters } \\
\text { of refuse) }\end{array}$ & Remarks \\
\hline 1 & Olusosun & 8404 & 149048.86 & 49 \\
2 & Solous ii & 1864 & 34029.11 & 11 \\
3 & Solous iii & 2460 & 45326.40 & 15 \\
4 & Ewuelepe & 1486 & 41594.59 & 14 \\
5 & Epe & 1161 & 32700.63 & 11 \\
& Total & 15375 & 302699.59 & 100 \\
\hline
\end{tabular}

Source: LAWMA

Table 6: Waste volume for the month of September, 2014(Cubic meter)

\begin{tabular}{lllll}
\hline S/n & $\begin{array}{l}\text { Landfill } \\
\text { sites }\end{array}$ & $\begin{array}{l}\text { Truck } \\
\text { trips }\end{array}$ & $\begin{array}{l}\text { Total } \\
\text { (cubic meters } \\
\text { of refuse) }\end{array}$ & Remarks \\
\hline 1 & Olusosun & 9044 & 160277.55 & 54 \\
2 & Solous ii & 1747 & 32040.55 & 11 \\
3 & Solous iii & 2476 & 45384.30 & 15 \\
4 & Ewuelepe & 1188 & 30532.18 & 10 \\
5 & Epe & 1091 & 30557.18 & 10 \\
& Total & 15546 & 298791.81 & 100 \\
\hline
\end{tabular}

Source: LAWMA

\section{PERFORMANCE INDEX OF MANAGING WASTE IN LAGOS}

Lagos is entirely a marine island which is largely surrounded by water. The population of Lagos has been reported to have reached $21,883,047$ million people in 2014and this is a huge challenge considering the volume of generated from Lagos. Adewole [2] has reported that Lagos lagoon is believed to have been absorbing $10000 \mathrm{~m}^{3}$ volume of industrial and associated wastes daily which has resulted in the pollution of water for human consumption. With a minimum number of 2000 people relocating to Lagos on daily basis from other part of the country, Lagos is likely to be the fastest populating cities in the Africa. Managing waste in Lagos is may be a herculean task in view of daily migration to Lagos without proper planning. Waste management in Lagos is principally the constitutional responsibility of Lagos waste management authority (LAWMA) and their giant strides in curtailing waste is widely acknowledged to be monumental[15]. In this study, waste volume for the month of January, July and September, 2014 were sourced from LAWMA to serve as a pilot test for this research.

LAWMA is currently faced with the challenge of waste management as reports show that waste volume recently rise from 10,000 to 12,000 tonnes[17]. In Table 5 to 7 , it is shown that waste is still a challenge as evident the proportion of data released. In January 2014 alone, waste volume stood at $340,016.62 \mathrm{~m}^{3}$, which to a larger extent, has indicated that existing methods to contain these wastes may not be sustainable.

\section{PROPORTION OF PLASTIC WASTES IN LAGOS}

Scarlatet al [27] investigated African proportion of plastic wastes generated by income earner and gave a tabular representation as shown in Table 7. According to the authors, plastic waste is easily generated and efforts have to be taken in view of its energy potential.

Table 7: Proportion of constituent of Wastes. Adapted from Scarlatet al [27].

\begin{tabular}{llllll}
\hline Income earners & Organic range $\%$ & Paper range $\%$ & Plastic\% & Glass\% & Metals\% \\
\hline Low income & $64(18-22)$ & $6(2-21)$ & $9(1-20)$ & $3(1-12)$ & $3(1-12)$ \\
Low medium income & $59(20-76)$ & $10(2-18)$ & $13(2-18)$ & $4(1-9)$ & $2(1-20)$ \\
Upper medium & $54(5-70)$ & $15(7-37)$ & $12(3-36)$ & $4(1-13)$ & $3(1-8)$ \\
High income & $25(4-56)$ & $30(4-68)$ & $11(1-24)$ & $7(1-13)$ & $6(1-16)$ \\
Africa & $57(18-88)$ & $9(2-21)$ & $13(1-20)$ & $4(1-5)$ & $4(1-5)$ \\
\hline
\end{tabular}


In fairness to Lagos state government, concerted efforts are being explored to manage waste volume but there appear to be enormous waste volume to contend with. Plastic waste appears to have been the most ravaging wastes in recent times as virtually daily materials and utilities in Lagos homes contains 70\% plastics[18].According to Salamiet al [26], plastic wastes account for $15 \%$ of total waste volume and some of the organic materials may still be classified as plastic material as fraction of its production is from plastic materials. The authors characterised Lagos wastes in the category presented in Table 8.

\section{Table 8: Characterization of waste proportion}

\begin{tabular}{lcc}
\hline Category & Volume(tonnes) & $\begin{array}{c}\text { Percent } \\
\text { proportion }\end{array}$ \\
\hline Organic & 5580 & 62 \\
Plastic & 1350 & 15 \\
Paper & 900 & 10 \\
Glass & 360 & 4 \\
Silts & 630 & 7 \\
Ashes & 180 & 2 \\
\hline Total & 9000 & 100 \\
\hline
\end{tabular}

Rigamontiet al [25] had equally given precise fraction of plastic in municipal solid waste. According to their study, plastic has definite proportion in municipal solid wastes which make plastic waste a major waste in need of solution (see Table 10). For example, it was reported further that plastic in municipal solid wastes is made of polyethylene terephthalate (PET) or high density polyethylene (HDPE), of soft plastic or plastic films made of low density polyethylene (LDPE) and of hard plastic made of HDPE. The remaining plastic material fraction is regarded as non-recyclable mixed plastic in which high proportion is non plastic. This assertion was further supported by the authors [22, 28]. In the same vein, Al-Salemet al [3] investigated recovery process of plastic wastes having considered all methods in the developing countries and concluded that recycling and energy recovery appeared to be more pragmatic and sustainable if developing countries desired to catch-up with the millennium development goals (MDG).

Table 9: Weight fraction of Plastics according to Rigamontiet al [25]

\begin{tabular}{cc}
\hline Proportion of plastic fraction & \% weight average \\
\hline Bottles & 27 \\
Soft & 36 \\
Hard & 11 \\
Non-recyclable & 26 \\
\hline
\end{tabular}

\section{CONCEPT OF ENERGY RECOVERY FROM PLASTIC WASTES.}

Energy has always been a debating issue in Nigeria especially in Lagos where there is large deficit in power generation and transmission. The concept of source reduction of wastes has been widely published by many authors $[5,16]$ and is currently receiving attention from government. Energy from wastes may be conceptualised in two perceptions. The first concept has the idea of power generation from wastes which is critical to emerging cities like Lagos while the second agenda evolves from fuel energy in which sizeable authors $[20,27,30]$ have reported. This idea if properly harmonised can serve as a role in minimizing wastes and also give more room for power development and growth. This study was aimed at $\mathrm{x}$ raying the possibility of energy generation from wastes as widely championed by United Nation to save the environment from imminent collapse. Nature is in dire need of attention as reported by Bajićet al [7] which is one of the goal of MDG in terms of sustainable development and it is high time Lagos looked into energy development from waste in view of its critical location in Nigeria economic setting. According to Wonget al [33] plastics wastes could be converted into energy using thermal and catalytic pyrolysis, microwave-assisted pyrolysis and fluid catalytic cracking.

Igoniet al [19] had reported a comparative volume of energy derivable from Port Harcourt waste and this study was critical to estimate the volume of waste convertible to energy generation in Lagos environment, the entire area has to be delineated, a procedure widely reported by[6]. The procedural process involves core use of Simpson's rule for the estimation of volumes, also called the Prismoidal formula.

The rule may be illustrated mathematically as follows:

$$
X=\frac{a}{3}\left[A_{1}{ }^{+4} A_{2}{ }^{+2} A_{3}{ }^{+4}+\cdots,+A_{n-1} A_{n}\right]
$$

With this equation the entire volume of waste in Lagos can be estimated while $A_{1}$ is considered first area or local government council or development area of Lagos state.

According to Beathet al [9] energy content in waste volume may be estimated by using the relation

$$
E=0.051[F+33.6(C P)]+0.352(P L R)
$$

The content of total solid (TS) and volatile solids (VS) will be determined as recommended in the standard method. 


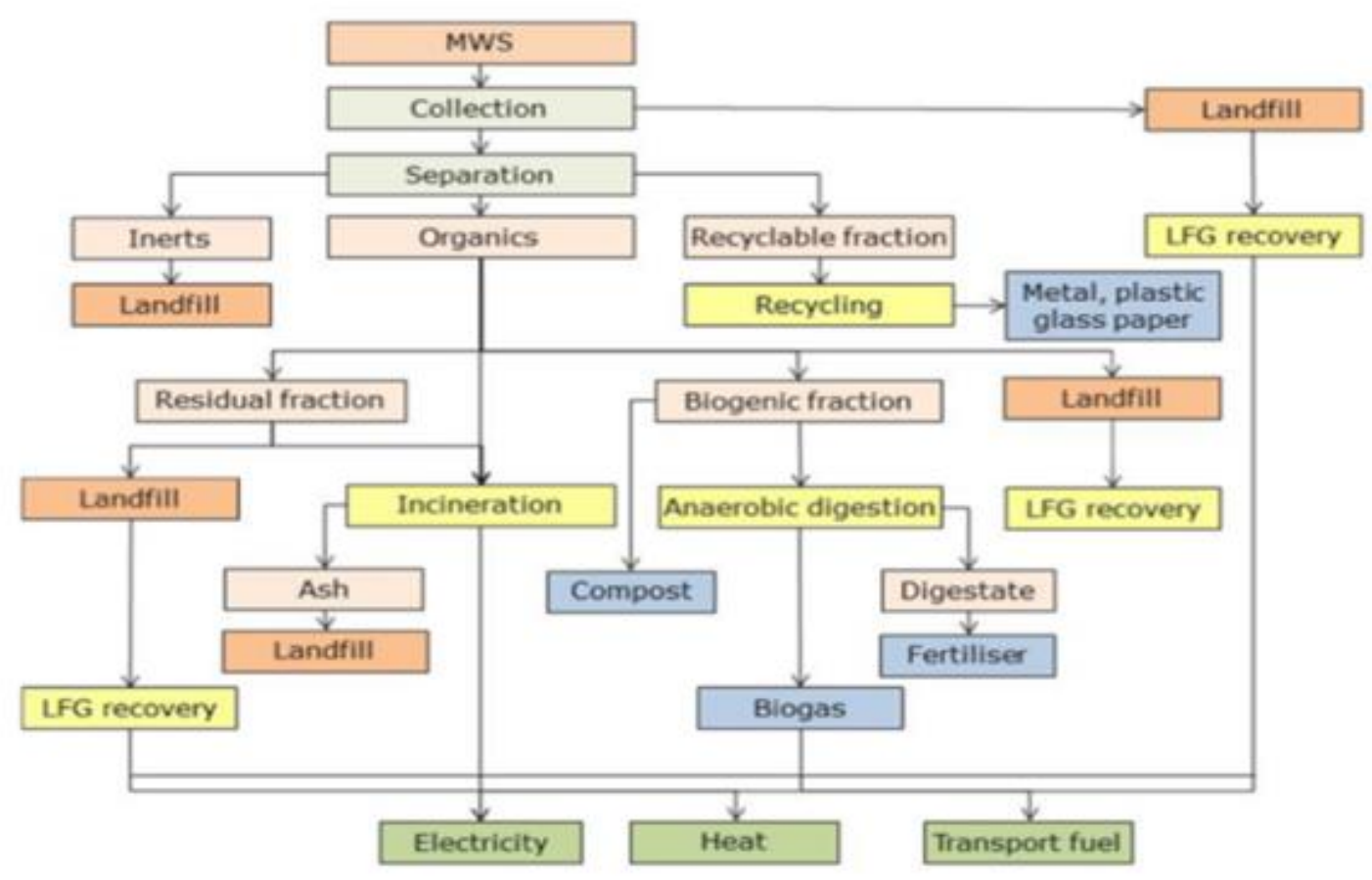

Figure 2: Framework mechanism of energy generation from wastes. Adapted from [27]

This will further enhance the determination of biodegradable content of the waste using the equation prescribed by Kiely, in which

$B F=0.83-0.028 L C$

In (3), $\mathrm{BF}$ is the biodegradable content of the waste and $\mathrm{LC}$ is the lignin content in the waste

Many authors $[10,13]$ have developed means of energy recoverable from waste. Several technologies are currently being used such as incineration, biochemical conversion which has been reported to have produced good result in developed countries. Schematic representation of this process is shown in Figure 2. Other recovery process are discussed in section 4.1 and 4.2

\subsection{Conversion of Plastic Waste to Biogas.}

Biogas production from waste is currently being explored in the literatures as most friendly alternative waste management system. The United Nations Development Programme (UNDP) energy report further gave credence to this concept and reported that Africa need to take a cue from developed countries by developing installation of small biogas plants to contain the growing waste in the continent. Production of biogas from anaerobic digestion of organic materials particularly from the municipal waste may likely be the solution Lagos government need to explore in her bid to solve the epileptic power supply in the state. Sufficient biogas generated from small to large scale biogas plant can be used for running gas turbines and generating electricity for remote and disconnected communities. Several researchers have described biogas production from municipal waste as a reliable technology and a sustainable innovation in electricity and power growth in developing countries. Now that the decentralization of electricity distribution and generation is already taking root in Nigeria, Lagos could independently use this platform as a pilot test for energy generation from waste.

\subsection{Combustion of Municipal Waste for Energy Utilization}

A lot of studies have equally confirmed that biodegradable and combustible components of municipal waste could be processed for electricity generation. Many combustible organic materials from municipal and other sources of wastes that cannot be regenerated can be a source of fuel for incineration in major poultry industries. Plastic waste is reported to have high calorific value in view of its energy content. Some of these combustible materials from the plastic waste which are currently being burnt in the open can be channelled into electricity generation.

\section{CONCLUSION}

In light of the volume of waste generated in Lagos and its associated management challenges, it is therefore 
necessary for government to explore energy generation in future plans. The challenge is enormous and it behoves on regulatory agency to partner with expert on how to combat the challenge. Another possible way to inject sanity into waste management plans in Lagos is for government to privatise waste in its entirety. Waste appears to be a business in developed countries and unnecessary political interference has been a draw back in some of the developing countries. Laws need to be enforced where necessary so that it can serve as a deterrence to others. Waste minimisation seemed a mirage in Lagos as noticed in the data supplied for July and September, 2014. For any country to achieve millennium development goal, further attention need to be paid to the concept of waste to energy development.

\section{ACKNOWLEDGEMENT}

The authors wish to appreciate Lagos waste management agency (LAWMA) for the data used in this study. Appreciation also goes to the authors of many literatures that have served as a guide to develop this manuscript. The corresponding author wishes to appreciate the useful comments provided by the two anonymous reviewers and the guest editor who handle our paper.

\section{REFERENCES}

[1] Adaramola, M. S., O. M. Oyewola, O. S. Ohunakin, and 0. O. Akinnawonu, Performance evaluation of wind turbines for energy generation in Niger Delta, Nigeria. Sustainable Energy Technologies and Assessments, 2014. 6(0): p. 75-85.

[2] Adewole, A. T., Waste management towards sustainable development in Nigeria: A case study of Lagos state. Int. NGO Journal, 2009. 4(4): p. 173-179.

[3] Al-Salem, S., P. Lettieri, and J. Baeyens, Recycling and recovery routes of plastic solid waste (PSW): A review. Waste Management, 2009. 29(10): p. 26252643.

[4] Aliyu, A. S., J. O. Dada, and I.K. Adam, Current status and future prospects of renewable energy in Nigeria. Renewable and Sustainable Energy Reviews, 2015. 48(0): p. 336-346.

[5] Aliyu, A. S., A .T. Ramli, and M.A. Saleh, Nigeria electricity crisis: Power generation capacity expansion and environmental ramifications. Energy, 2013. 61(0): p. 354-367.

[6] Ayotamuno, J. M. and A. E. Gobo, Municipal solid waste management in Port Harcourt, Nigeria: Obstacles and prospects. Management of Environmental Quality: An International journal, 2004. 15(4): p. 389-398.
[7] Bajić, B. Ž., S. N. Dodić, D. G. Vučurović, J.M. Dodić, and J.A. Grahovac, Waste-to-energy status in Serbia. Renewable and Sustainable Energy Reviews, 2015. 50(0): p. 1437-1444.

[8] Barros, C. P., A. Ibiowie, and S. Managi, Nigeria's power sector: Analysis of productivity. Economic Analysis and Policy, 2014. 44(1): p. 65-73.

[9] Beath, S., P. Davies, A. Papadopoulou, A. Khan, R. Buick, J. Corkery, P. Gornall, and I. Booth, Parenteral nutrition-Related cholestasis in postsurgical neonates: Multivariate analysis of rick factors. Journal of Paediatric Surgery, 1996. 31(4): p. 604606.

[10] Bello, M., M. K. Lawan, T. Aluwong, and M. Sanusi, Management of slaughter houses in northern Nigeria and the safety of meat produced for human consumption. Food Control, 2015. 49(0): p. 34-39.

[11] Bernstad Saraiva Schott, A. and A. Cánovas, Current practice, challenges and potential methodological improvements in environmental evaluations of food waste prevention - A discussion paper. Resources, Conservation and Recycling, 2015. 101(0): p. 132-142.

[12] Biron, M., The Plastics Industry: Economic Overview, in Thermoplastics and Thermoplastic Composites (Second Edition), M. Biron, Editor. 2013, William Andrew Publishing. p. 31-131.

[13] Cheung, W. M. and V. Pachisia, Facilitating waste paper recycling and repurposing via cost modelling of machine failure, labour availability and waste quantity. Resources, Conservation and Recycling, 2015. 101(0): p. 34-41.

[14] Dionco-Adetayo, E. A., Utilization of wood wastes in Nigeria: a feasibility overview. Technovation, 2001. 21(1): p. 55-60.

[15] Elias, P. and A. Omojola, Case study: The challenges of climate change for Lagos, Nigeria. Current Opinion in Environmental Sustainability, 2015. 13(0): p. 74-78.

[16] Evangelisti, S., C. Tagliaferri, R. Clift, P. Lettieri, R. Taylor, and C. Chapman, Life cycle assessment of conventional and two-stage advanced energy-fromwaste technologies for municipal solid waste treatment. Journal of Cleaner Production, 2015. 100(0): p. 212-223.

[17] Ezeah, C. and C. L. Roberts, Waste governance agenda in Nigerian cities: A comparative analysis. Habitat International, 2014. 41(0): p. 121-128.

[18] Fu, H.-z., Z.-s. Li, and R.-h. Wang, Estimating municipal solid waste generation by different activities and various resident groups in five provinces of China. Waste Management, 2015. 41(0): p. 3-11.

[19] Igoni, A. H., M. J. Ayotamuno, S.O.T. Ogaji, and S.D. Probert, Municipal solid-waste in Port Harcourt, Nigeria. Applied Energy, 2007. 84(6): p. 664-670. 
[20] Jekayinfa, S. O., F. A. Ola, S. O. Afolayan, and R. O. Ogunwale, On-farm energy analysis of plantain production in Nigeria. Energy for Sustainable Development, 2012. 16(3): p. 339-343.

[21] Kofoworola, O. F., Recovery and recycling practices in municipal solid waste management in Lagos, Nigeria. Waste Management, 2007. 27(9): p. 1139-1143.

[22] Lazarevic, D., E. Aoustin, N. Buclet, and N. Brandt, Plastic waste management in the context of a European recycling society: comparing results and uncertainties in a life cycle perspective. Resources, Conservation and Recycling, 2010. 55(2): p. 246259.

[23] Oyake-Ombis, L., B. J. M. van Vliet, and A. P. J. Mol, Managing plastic waste in East Africa: Niche innovations in plastic production and solid waste. Habitat International, 2015. 48(0): p. 188-197.

[24] Permana, A. S., S. Towolioe, N.A. Aziz, and C.S. Ho, Sustainable solid waste management practices and perceived cleanliness in a low income city. Habitat International, 2015. 49(0): p. 197-205.

[25] Rigamonti, L., M. Grosso, J. Møller, V. Martinez Sanchez, S. Magnani, and T.H. Christensen, Environmental evaluation of plastic waste management scenarios. Resources, Conservation and Recycling, 2014. 85: p. 42-53.

[26] Salami, L., A. Susu, R. Patinvoh, and 0. Olafadehan, Characterisation study of solid wastes: a case of Lagos state. International Journal of Applied Science and Technology, 2011. 1(3).
[27] Scarlat, N., V. Motola, J.F. Dallemand, F. MonfortiFerrario, and L. Mofor, Evaluation of energy potential of Municipal Solid Waste from African urban areas. Renewable and Sustainable Energy Reviews, 2015. 50(0): p. 1269-1286.

[28] Shonfield, P., LCA of Management Options for Mixed Waste Plastics. WRAP, UK, 2008.

[29] Song, Q., J. Li, and X. Zeng, Minimizing the increasing solid waste through zero waste strategy. Journal of Cleaner Production, 2015. 104(0): p. 199210.

[30] Teixeira, S., E. Monteiro, V. Silva, and A. Rouboa, Prospective application of municipal solid wastes for energy production in Portugal. Energy Policy, 2014. 71(0): p. 159-168.

[31] Tuppad, P., N. Kannan, R. Srinivasan, C.G. Rossi, and J.G. Arnold, Simulation of agricultural management alternatives for watershed protection. Water Resources Management, 2010. 24(12): p. 3115-3144.

[32] Vasudevan, R., A. Ramalinga Chandra Sekar, B. Sundarakannan, and R. Velkennedy, A technique to dispose waste plastics in an ecofriendly way Application in construction of flexible pavements. Construction and Building Materials, 2012. 28(1): p. 311-320.

[33] Wong, S. L., N. Ngadi, T.A.T. Abdullah, and I.M. Inuwa, Current state and future prospects of plastic waste as source of fuel: A review. Renewable and Sustainable Energy Reviews, 2015. 50(0): p. 11671180. 